\title{
Declaration of War: A Dead LetTer or AN INVITATION TO STRUGGLE?
}

\section{Thomas Halper*}

\begin{abstract}
The Constitution's declaration of war requirement, superficially straightforward but actually full of ambiguities, originated in a fear of presidential usurpation and recklessness. Yet Congress has responded to political incentives and has declined the assertive role assigned to it. The check on usurpation and recklessness has eroded almost to the vanishing point.
\end{abstract}

\section{KEYWORDS}

Declaration of War, AUMF, President, Congress, Supreme Court

\section{CONTENTS}

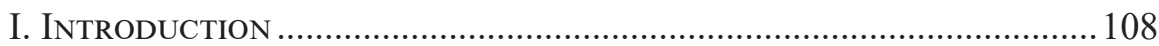

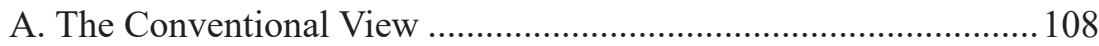

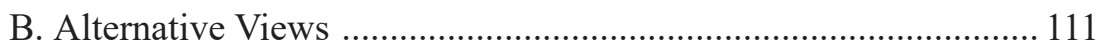

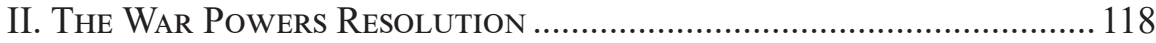

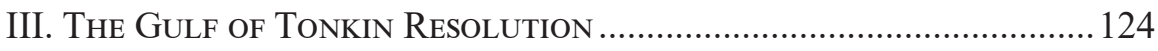

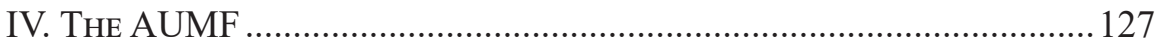

V. The Threats of President Trump ………………........................... 130

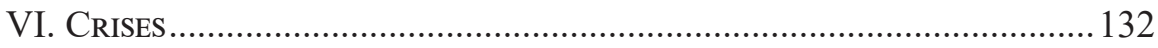

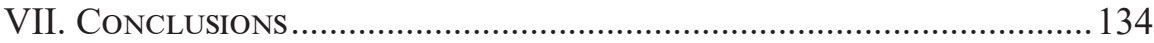

Professor, Political Science, Baruch College \& CUNY Graduate Center. Thomas.Halper@, baruch.cuny.edu. I am grateful to Benedetto Fontana and Stanley Renshon for their many insightful suggestions 


\section{INTRODUCTION}

"North Korea best not make any more threats to the United States," warned President Trump. "They will be met by fire and fury like the world has never seen." Congressional Democrats' reaction was apoplectic. Senator Dianne Feinstein (DCA) called the remarks "bombastic"; Representative Eliot Engel (D-NY) thought the President was "unhinged"; Senator Ben Cardin (D-MD) denounced the talk as "bluster and provocative"; Senator Charles Schumer (D-NY) said it was "reckless rhetoric"; ${ }^{2}$ Representative David Cicillini (D-RI) criticized its "escalating rhetoric"; Representative Betty McCollum (D-MN) found it "dangerous"; and Representative Ted Lieu (D-CA) thought it was "provocative." 3 Could the President, entirely on his own, order such an attack? None of the Democratic critics, so unsparing in their condemnation, raised the question. Yet it would seem as obvious as a moose on a highway, for the Constitution announces that "The Congress shall have the power to . . . declare war"? ${ }^{4}$ What could be simpler?

\section{A. The ConVENTIONAL VIEW}

The conventional view is that the Constitution, having "conferred virtually all of the war-making powers" upon Congress, leaves the President only the power "to repel 'sudden attacks." ${ }^{5}$ Congress' power to start or enter an ongoing war, in turn, must take the form of an explicit resolution to that effect. The rationale, as Madison wrote Jefferson, is "that the executive is the branch of power most interested in war, and most prone to it. [The Constitution] has accordingly with studied care, vested the question of war in the legislature." ${ }^{\prime}$ Madison, who feared war as expensive, corrupting, and destructive of the separation of powers, wrote these words while President Adams was waging a surreptitious war with France. A half century later, Lincoln, provoked by President Polk's Mexican War, explained, "Kings had always been involving and impoverishing their people in wars, pretending generally, if not always, that the good of the people was the object. This, our Constitution understood to be the most oppressive of all kingly oppressions; and they resolved to frame the Constitution so that no one man should hold the power of bringing this oppression

Noah Bierman, Trump Warns North Korea of Fire and Fury, L.A. Times, Aug. 8, 2017.

2 Jeremy Herb, Lawmakers Slam Trump's "Fire and Fury" toward North Korea, CNN (Aug. 9, 2017), https://edition.cnn.com/2017/08/08/politics/lawmakers-trump-fire-fury-northkorea-mccain/index.html.

3 Rebecca Shabad, Democrats Blast Trump's "Fire and Fury" Warning to North Korea, CBS News, (Aug. 8, 2017), https://www.cbsnews.com/news/democrats-blast-trumps-fire-andfury-warning-to-north-korea/.

$4 \quad$ U.S. CONST. art. I, $\S 8$.

5 Raoul Berger, War-Making by the President, 121 U. PA. L. Rev. 29, 82 (1972).

6 Letter to Thomas Jefferson, Apr. 2, 1798, JAMES MADISON: Writings 586 (Jack Rakove ed. 1999). For Madison, the Constitution's two years appropriations rule for the army was "the best possible precaution against danger from standing armies." THE FeDERALIST 41, at 201 (James Madison) (George W. Carey \& John McClellan eds. 2001/1787). Though Madison the Framer insisted that war be a last resort and be widely backed by Congress and the public, Madison the President stumbled into the War of 1812, which was neither. 
upon us." Or as one authority put it, "our system rests on the assumption that many minds are more trustworthy than one on questions of war and peace." "The President may recommend war, as Franklin Roosevelt did after the bombing of Pearl Harbor, but only Congress may declare war, which it promptly did in a pair of formal statutes. ${ }^{9}$ The constitutional role of commander-in-chief, from this vantage point, "is simply one of the means to the fundamental purpose of the presidency, that is, seeing to the execution of the law." 10

With the conventional view, "declare" is assumed to mean "initiate." But there are a pair of obvious problems here. First, in ordinary speech, "declare" does not mean "initiate." "Declare" means to make known or state emphatically; "initiate" means to start. The Declaration of Independence, for example, driven by "a decent respect to the opinions of mankind," explained why the American colonies had decided "to dissolve the political bands" which connected them with Britain. ${ }^{11}$ Similarly, in ancient times, Thucydides reports that the Spartans, seeing their treaty with Athens broken, voted to declare war, ${ }^{12}$ and the Roman Republic required that a collegium of priests certify wars, both to guarantee that the wars were just. ${ }^{13}$ Second, if the Framers meant "initiate," why did they not use that word? Why assume that they really intended to use a word they failed to use? As a matter of fact, they first used "make," which is tolerably close to "initiate," but then decided to replace it with "declare," 14 fearing that "make" might imply operational responsibility.

Those who believe that "declare" means "initiate" often go on to claim that the only valid constitutional declaration of war is one that is expressly labeled as such. ${ }^{15}$ The purpose of the declaration, from this perspective, is to use the presumptive voice of the people to restrain the President, forge a presidential-congressional partnership, and legitimize the war effort. It then follows, like Polonius' night and

7 Letter to William H. Herndon, Feb. 15, 1848. 1 The Collected Works of Abraham LinColn 451-52 (Roy P. Basler ed. 1953) (emphasis in original). Like Madison, Lincoln did not always practice what he preached. As President, for example, he hired and fired generals, suspended habeas corpus, and freed the slaves in the rebellious states without pausing to consult with Congress, arguing that "by the law of war, property ... may be taken as needed." Letter to James C. Conkling, Aug. 26, 1863, id. 6: 409.

8 Merlo J. Pusey, The Way We Go to War 5 (1969); Alexander George, The Case for Multiple Advocacy in the Making of Foreign Policy, 66 Am. Pol. Scr. Rev. 751 (1972).

9 Joint Resolution of Dec. 8 Pub. L. No. 77-328, 55 Stat. 795 (1941) (Japan) and Joint Resolution of Dec. 12 Pub. L. No. 77-331, 55 Stat. 796 (1941) (Germany). Fifty members of the House opposed Wilson's call for a declaration of war in 1917. Of course, nothing comparable to the Pearl Harbor attack had occurred.

10 Wilfred E. Binkley, The Man in the White House: His Powers and Duties 188 (rev. ed. 1964); Charles Fairman, The President as Commander-in-Chief, 11 J. Politics 145 (1949).

11 DeCLARATION OF InDEPENDENCE (U.S.1776).

12 Thucydides, History of the Peloponnesian War 187 (Richard Crawley trans., Penguin Classics rev. ed. 1972).

13 Francisco Pina Polo, The Consul at Rome: The Civil Functions of the Consuls in THE RoMAN REPUBLIC 188-91 (2011).

142 The Records of the Federal Convention of 1787 318-19 (Max Farrand ed.1911).

15 E.g., J. Gregory Sidak, To Declare War, 41 Duke L.J. 27 (1991); MichaEl J. GlenNon, Constitutional Diplomacy 81 1990). 
day, that with only eleven such declarations covering only five wars, the last in $1942,{ }^{16}$ but some 200 military actions, the declaration requirement is a dead letter. ${ }^{17}$

The war declaration provision, so important but also so cryptic, leaves an abundance of practical questions unanswered. For example, does Congress' power to declare war limit the President's power to wage war? Does a declaration of war compel the President to wage war? The President has a constitutional duty to "take care that the laws be faithfully executed," 18 but as commander in chief ${ }^{19}$ may he conclude that the war that Congress assigned him is a mistake? Does a congressional declaration require the President's signature, like ordinary laws, ${ }^{20}$ or as its having been singled out in the Constitution, is it spared from this requirement? ${ }^{21}$ The potentially overlapping responsibilities of a Congress declaring and funding war and a President serving as commander in chief seem guaranteed to result in conflict, confusion, misunderstanding, and deceit.

It is not even clear what constitutes a declaration. Must it be a formal, labeled declaration, like Roosevelt's? The Constitution does not say. But the necessary and proper clause gives Congress the authority to implement its powers, so that when it adopts an authorization for the use of military force or allocates funds for this purpose, it is formally, if implicitly, approving engaging in military conflict. That is, the act of implementing implies the prior existence of a larger decision to be implemented. In Bas v. Tingy ${ }^{22}$ (1800), a salvage case that arose during hostilities with France, the Supreme Court held that as "Congress had raised an army, stopped all intercourse with France, dissolved our treaty, built and equipped ships of war, and commissioned private armed ships ... the degree of hostility meant to be carried on was sufficiently described without declaring war or declaring that we were at war." ${ }^{23}$ Absent a formal declaration of war, war existed and Congress had authorized it.

16 Rumania on June 5. See Joint Resolution of June 5 1942, ch. 325, 56 Stat. 307 (1942). A few years earlier, fear that Congress could be pressured into declaring war led isolationists to propose a constitutional amendment providing that, except in case of invasion or attack, a declaration of war must be approved by a majority of the public in a national referendum.

17 See, e.g., Brien Hallett, The Lost Art of Declaring War $34-36$ (1998); David B. Sentelle, National Security Law: More Questions than Answers, 31 Fla. St. U. L. Rev. 1, 5-6 (2003). In the popular press, see, e.g., Neil A. Lewis, Mideast Tensions: Sorting Out Legal War Concerning Real War, N.Y. TIMES, Nov. 15, 1990, at 18; Jonathan Schell, When Is the End? The NATION, June 13, 2011. The absence of formal war declarations is not a peculiarly American phenomenon.

18 U.S. CONST. art. II, $\S 3$.

19 U.S. CONST. art. II, § 2.

20 Alexander Bickel et al., Indochina: The Constitutional Crisis, 116 Cong. Rec. 15,410 (1970); Simeon E. Baldwin, The Share of the President of the United States in a Declaration of War, 12 AM. J. INT'L. L 1 (1918).

21 Louis Henkin, Constitutionalism, Democracy, and Foreign Affairs 39 (1990); Stephen L. Carter, The Constitutionality of the War Powers Resolution, 70 VA. L. Rev. 101, 131 (1984). President John Adams successfully countered Congress' calls for a declaration of war against France. John Patrick Diggins, John Adams 55-80 (2003). But for many years, Presidents have taken the lead in urging wars. As none have refused to sign such declarations, the dispute is entirely speculative.

224 U.S. 37 (1800).

23 Id. at 41. A similar point was made in another salvage case arising out of the same hostilities, Talbot v. Seeman, 5 U.S. 1, 33 (1801), as well as in a case approving President Lincoln's blockade of Confederate ports. Prize Cases, 67 U.S. 635, 668 (1863). 


\section{B. ALTERNATIVE VIEWS}

The alternative to the congressionally centered approach is one that is presidentially centered. Hamilton in Federalist 70 argued that a successful executive must have energy, which we would approximate as leadership, and energy, he maintained, presupposes unity, duration, and adequate provision for its support. Hence a President consisting of one person (and not a cabinet) and having its own basis of power (and not being a creature of the legislature).${ }^{24}$ Given these attributes, Hamilton believed, a President will have a decent chance at success, and given these, it makes sense to hold him responsible for his decisions. In foreign and security affairs, the argument goes, leadership is even more important, for it is necessary that the nation speak with one voice so that others do not exploit internal divisions, and so the President's role here is naturally magnified.

Where does this leave Congress? Since it controls the purse, it can alter or reverse any presidential policy at any time simply by refusing to fund it or it can seek to marshal public opinion against the policy through hearings, investigations, speeches, and so forth. In general, though, Congress is simply bypassed, like a rush hour traffic jam, with the observation that "most modern conflicts are not 'undeclared' wars, but rather wars declared by the President," ${ }^{25}$ who announces that war had begun and outlines its goals and justifications. A "well-accepted understanding of the President's powers," consistent "with the historical practice [and] the considered judgment of Congress," all point to greater presidential discretion. ${ }^{26}$ Nor is this stress on executive authority a peculiarly modern phenomenon. From 1700-1787, the year of the constitutional convention, thirty-eight wars were fought in the Western world, of which precisely one was declared. ${ }^{27}$ No wonder Hamilton in Federalist 25 observed that "the ceremony of a formal declaration of war has of late fallen into disuse. ${ }^{28}$

Yet while presidential acts may indeed constitute credible de facto declarations of war, it is hard to see how these extraconstitutional rationales can substitute for congressional authorizations, given that the Constitution makes no mention of presidential declarations; even a backer of this view concedes that the Constitution by implication "denies [the power] to the President." 29 Perhaps the point is that if Congress, the aggrieved party, does not object, neither should the courts. This, however, misconstrues the purpose of the Constitution, which is not to safeguard the interests of Congress, but instead the interests of the people.

John Yoo, a former deputy assistant attorney general in President George W. Bush's Office of Legal Counsel, took the presidentially centered alternative a step farther, attracting considerable attention along the way. Yoo, citing Samuel

The Federalist 71 (Alexander Hamilton), supra note 6, at 365.

25 Michael D. Ramsey, Presidential Declarations of War, 37 U.C. DavIS L. Rev. 321, 324 (2003).

26 Walter Dellinger, War and Responsibility: A Symposium on Congress, the President, and the Authority to Initiate Hostilities, 50 U. Miami L. Rev. 107, 113 (1995).

27 John F. Maurice, Hostilities without Declaration of War, From 1700 to 1865 12-27 (1883). But cf., Frederic J. Baumgartner, Declaring War in Early Modern Europe 1-7 (2011).

28 The Federalist 25 (Alexander Hamilton), supra note 6, at 124.

29 Ramsey, supra note 24, at 357. 
Johnson's famous Dictionary of the English Language, which appeared in $1755,{ }^{30}$ maintained that Congress' power to declare war is merely the power to announce the existence of a state of war under international law, a power that historically has been exercised not to start wars, but instead once they are well underway to notify interested parties of the changed legal status. ${ }^{31}$ President Truman, who evaded Congress by terming the Korean War a police action, might have embraced this view. Facing the onset of the Cold War, he favored a presidency with wide discretion and not confined by a Congress sometimes caught up in partisanship. Of Polk, who connived to start the Mexican War, Truman admired that he "regularly told Congress to go to hell on foreign policy matters." 32 The declare war clause, from this point of view, "does not add to Congress' store of war powers at the expense of the President," ${ }^{33}$ and the President would, therefore, retain the sole power to initiate war for any reason he found persuasive. Hence, the President, followed by an aide carrying a "football" containing launch codes, may on his own authority call for nuclear strikes at any target and at any time.

A "defining constitutional moment" 34 was United States v. Curtiss-Wright Export Corp. (1936), ${ }^{35}$ which though it did not concern war powers, appeared to acknowledge vast areas of presidential discretion in this area. Congress, wishing to end the Chaco War between Paraguay and Bolivia, passed a resolution permitting the President to ban weapons sales to either country, if he finds that the ban "may contribute to the reestablishment of peace." 36 President Roosevelt declared the condition met and proclaimed the ban; Curtiss-Wright conspired to sell fifteen machine guns to Bolivia and was indicted for violating the ban; a lower court sided with Curtiss-Wright, calling the resolution "an invalid delegation of legislative power." 37

The Supreme Court, in an opinion written by Justice Sutherland but likely shaped by Chief Justice Hughes, ${ }^{38}$ distinguished between external and internal powers. The principle that power once delegated may not be re-delegated may apply to internal matters, Sutherland explained, but the national government is sovereign in external matters, its powers deriving not only from the Constitution, but also

30 John Yoo, The Powers of War and Peace: The Constitution and Foreign Affairs AfTER 9/11 145 (2005). However, Yoo adduces no evidence that the Framers adopted Johnson's definition.

31 John Yoo, War and the Constitutional Texts, 69 U. CHI. L. Rev. 1639, 1698 (2002). A similar argument was made some years before by Eugene V. Rostow, Once More Unto the Breach: The War Powers Act Revisited, 21 VAL. U. L. Rev. 1, 6 (1986).

32 Michael Beschloss, Presidents of War 462 (2018).

33 John Yoo, The Continuation of Politics by Other Means: The Original Understanding of War Powers, 84 Cal. L. Rev. 167, 295 (1996). See also, Robert F. Turner, Repealing the War Powers Resolution: Restoring the Rule of LaW in U.S. Foreign Policy 80-96 (1991); Eugene V. Rostow, Great Cases Make Bad Law: The War Powers Act, 50 Tex. L. Rev. 833 (1972).

34 Kimberley L. Fletcher, The Court's Decisive Hand Shapes the Executive's Foreign Affairs Policymaking Power, 73 MD. L. Rev. 247, 253 (2013).

299 U.S. 304 (1936).

Joint Resolution of May 28, ch. 365, 48 Stat. 811 (1934).

Fletcher, supra note 34, at 315.

38 Edward A. Purcell, Jr., Understanding Curtiss-Wright, 31 Law \& Hist. Rev. 653, 667-78 (2013). 
from the nature of sovereignty itself. As a practical matter, this meant that Congress "must often accord to the President a degree of freedom from statutory restriction . . . especially . . . in time of war." ${ }^{39}$ Sutherland buttressed this claim by referring to an "unbroken legislative practice" of delegating authority to the President. ${ }^{40}$ What later courts have not always acknowledged, however, is that Sutherland's arguments for presidential supremacy are mere unbinding dicta. ${ }^{41}$ There was no conflict with Congress in Curtiss-Wright, for in its resolution Congress had authorized the presidential ban, and the long historical practice would have been sufficient to make Sutherland's argument without his presidential references.

With the important exception of the Steel Seizure case, ${ }^{42}$ when the Court found neither constitutional nor statutory authorization for Truman's war time seizure of steel mills, the Court has generally been sympathetic toward the President. Even when it excoriated Lincoln for abusing his war powers by creating military tribunals where civilian courts were open and functioning, it waited till the war was over, eliminating the immediate practical effect of its decision. ${ }^{43}$ Hamilton's Federalist 70 arguments about presidential energy, ${ }^{44}$ made nearly two and a half centuries ago in a world without planes, missiles, and nuclear weapons, have carried the day.

And yet most of the Framers seem to have considered Congress the most powerful branch and to have been wary of presidential unilateralism, Edmund Randolph, for example, calling the executive "the foetus of monarchy." 45 Washington wrote that "no offensive expedition of importance can be undertaken until after [Congress] shall have deliberated upon the subject, and authorized such a measure." ${ }^{46}$ Madison and James Wilson, an advocate of a strong presidency, stated that the President's powers "do not include the right of war and peace." ${ }^{47}$ Marshall wrote, "The whole powers of war [in] the Constitution [are] vested in Congress." 48 Even Hamilton, the most prominent promoter of presidential power, conceded that the declaration clause meant "that it is the peculiar and exclusive province of Congress, when the nation is at peace, to change that to a state of war. . . it belongs

39 Fletcher, supra note 34, at 320.

$40 \quad$ Id. at 320.

41 Youngstown Sheet \& Tube v. Sawyer, 343 U.S. 579, 635-36 n.2 (1952).

42 Id. To a much smaller degree, Hamdan v. Rumsfeld, 548 U.S. 557 (2006) and Boumediene v. Bush, 553 U.S. 723 (2008) also saw the Court limit the President's war powers.

43 Ex parte Milligan, 71 U.S. 2, 127 (1866). Justice Davis declared, "No doctrine involving more pernicious consequences was ever invented by the wit of man than that any of [the Constitution's] provisions can be suspended during any of the great exigencies of government." See, at 121 . The same Court had passed on the opportunity to rule on the question during the war. Ex parte Vallandigham, 68 U.S. 243 (1864).

44 The Federalist 70, supra note 6.

45 The Records of the Federal Convention, supra note 14, at 168. Patrick Henry agreed that the Constitution "squints toward monarchy [because the] President may easily become king." Patrick Henry, Governor of Virginia, Address at the Virginia Ratifying Convention (Jun. 5, 1788). Virginia Convention, Debates and Other Proceedings of the CONVENTION OF ViRGinia 52 (1805).

4633 The Writings of George Washington 73 (John C. Fitzpatrick ed. 1940).

47 The Records of the Federal Convention, supra note 14, at 319. Madison believed "[t]hat the power to declare war is fully and exclusively vested in the legislature; that the executive has no right ... to decide the question, whether there is or is not cause for declaring war." 6 The Writings of JAMES MAdisOn 174 (Gaillard Hunt ed. 1906).

48 See Talbot, 5 U.S. 1 at 28. 
to Congress only to go to war." ${ }^{\text {49 }}$ So widespread was the consensus that it became a point of contention at ratification, where Anti-Federalists challenged "the wisdom of granting Congress the war power, not whether Congress possessed the war power." ${ }^{50}$ Thus, an originalist examination of the declare war clause concluded that "[b]ecause such a proclamation was thought to be the normal means by which war is created, Congress was thought to have the power to declare war." ${ }^{51}$ Perhaps, modern courts have taken Hamilton's Federalist arguments more seriously than he did.

In any case, reading the clause like Yoo, as if it reduced Congress to the role of a dispensable bystander, simply does not accord with the structure the Framers sought to bring into being. The rejoinder, that Congress can check the President by refusing to fund the war, is hardly realistic. ${ }^{52}$ If the President has committed troops to battle, Congress will find it exceedingly difficult to refuse to arm and support them, especially in the critical early days when patriotic fervor is likely to peak. ${ }^{53}$ This is particularly true in a time of an all-volunteer army, for casualties among draftees could have a potent effect undermining popular support for war, ${ }^{54}$ but this element no longer exists. Moreover, Yoo's argument would not only confer conventional military authority on the President, but would also carry with it a plenitude of related powers (trade restrictions, ${ }^{55}$ weapons production, ${ }^{56}$ electronic surveillance, ${ }^{57}$ among others) to be added to the President's portfolio. The constitutional system of separation of powers, as a result, could under Yoo be stretched out of all recognition.

If the meaning of "declare" is contested, so, too, is the meaning of "war." The Oxford English Dictionary defines "war" as "any active hostility or struggle between living human beings; a conflict between opposing forces or principles." But this is far too loose to help us constitutionally, for it does not even distinguish between the metaphorical and the literal. Hobbes' famous definition - "war consisteth not in actual fighting, but in the known disposition thereto"58 — also seems defective because it includes far too much and because the "disposition" is often known only in hindsight. (Hobbes' focus on an anarchic state of nature, however, plainly has implications for the international realm, which lacks an overarching power to enforce peace and order.) On the other hand, Grotius' by now conventional answer, ${ }^{59}$ war as

498 The Works of AleXander Hamilton 249 (Henry Cabot Lodge ed. 1971/1904).

50 Cameron O. Kistler, The Anti-Federalists and Presidential War Powers, 121 Yale L. J. 459, 467 (2011). Emphasis in original.

51 M. Andrew Campanelli, Kai Draper, \& Jack Stucker, The Congressional Understanding of the Declare War Clause, 24 J.L. \& PoL. 49 (2008). See also, Charles A. Lofgren, WarMaking under the Constitution: The Original Understanding, 81 YALE L.J. 672 (1972).

52 Stephen L. Carter, Going to War Over War Powers, Wash. Post, Nov. 18, 1990.

53 On the other hand, if the war has dragged on and become unpopular, Congress may refuse to fund it, as it did in 1975 with the Vietnam War.

54 John E. Mueller, War, Presidents and Public Opinion (1985).

55 50 U.S.C. $\S 1702(2012)$.

5650 U.S.C.A. $\S \S 4517,4531-34$ (West 2018).

$57 \quad 50$ U.S.C. $\S 1802(2012)$.

58 Thomas HobBes, Leviathan ch. 13 (Michael Oakeshott ed. 1960/1651).

59 Francis A. Beer, How Much War in History: Definitions, Estimates, Extrapolations and Trends (1974); Bernard Brodie, War and Politics (1974); Karl Deutsch \& Dieter Senghaas, A Framework for a Theory of War and Peace, in the Search for World ORDER: FeSTSCHRIFT FOR QUINCY WRIGHT 23-46 (Albert Lepawsky et al. eds. 1972). 
"the condition of those contending by force" ${ }^{\prime 60}$ or armed conflict, is rigidly narrow and fails to address war's infinite manifestations.

Which raises the question of the relation of casus belli to war. Casus belli may be used to justify a war, though a country need not act on them. But is the casus belli itself an act of war? The question is not only legal, but also empirical. Is supplying a naval escort for allied convoys on hostile seas ${ }^{61}$ or offering money, arms, and advice to combatants an act of war? ${ }^{62}$ Is a blockade, even if it is called a quarantine ${ }^{63}$ Is denying a foe access to essential goods, commodities, or financial markets? ${ }^{64}$ What of toxic propaganda or cyberattacks ${ }^{65}$ Was the raid that killed Osama bin Laden an act of war? ${ }^{66}$ If one party urges ordinary citizens to commit acts of violence against another nation, is the urging an act of war? Have the citizens' committed acts of war? If a partner in a mutual security pact is attacked, must a military response be authorized by Congress? ${ }^{67}$ Even if the nation is halfway around the world and of little importance to the United States? ${ }^{68}$

The International Criminal Tribunal for the Former Yugoslavia defined war as "armed force between states or protracted armed violence between governmental authorities and organized armed groups or between such groups within a state." ${ }^{\circ 9}$ In an age of terrorism, how do we distinguish protracted from sporadic violence? Suppose sporadic violence erupts over a protracted period. With states and their militant oppositions, each reserving legitimacy for themselves and denying it for the others, do we make the determination on the basis of ideals or self interest? Similarly, should we distinguish between offensive and defensive wars or does the distinction break down from the force of all sides invariably asserting only defensive motives? The George H. W. Bush administration justified the President's unilateral decision to send 28,000 troops to $\mathrm{Somalia}^{70}$ in 1992 in terms of protecting "those engaged in relief work ..., including members of the United States Armed Forces who have been and will be dispatched to Somalia to assist in that work."

60 Hugo Grotius, On the Law of War and Peace (Stephen C. Neff. ed., Cambridge Univ. Press 2012/1625).

61 James MacGregor Burns, Roosevelt: The Soldier of Freedom 141 (1970).

62 Mike Gravel, Pentagon Papers 179-214 (1971).

63 U.S. Dept. of State, Office of the Historian, The Cuban Missile Crisis 1961-1963, Vol. XI (1962).available at https://history.state.gov/historicaldocuments/frus1961-63v11.

64 Edward S. Miller, Bankrupting the Enemy: The U.S. Financial Siege of Japan Before Pearl Harbor (2007).

65 Matthew C. Waxman, Cyber-Attacks and the Use of Force: Back to the Future of Article 2(4), 36 YALE J. INT'L. L. 421 (2011).

66 Christopher Schaller, Using Force against Terrorists "Outside Areas of Active Hostilities" - The Obama Approach and the Bin Laden Raid Revisited, 20 J. ConfL. \& SeC. 195 (2015).

67 North Atlantic Treaty art.5, Apr. 4, 1949, 63 Stat.2241, 34 U.N.T.S. 243.

68 President Trump wondered aloud whether the United States should adhere to article 5 of the North Atlantic Treaty and intervene if Montenegro were attacked. Eileen Sullivan, Trump Questions the Core of NATO: Mutual Defense, Including Montenegro, N.Y. TIMES, July 18, 2018, at A8.

69 Prosecutor v. Tadić, Case No. IT-04-84-A 193, ICTY (2010).

70 Stephen F. Burgess, Operation Restore Hope: Somalia and the Frontier of the New World Order, in From Cold War to the New World Order: The Foreign Policy of George H. W. Bush 259 (Meena Bose \& Rosanna Perotti eds. 2002).

71 William P. Barr, Authority to Use United States Military Forces in Somalia, 16 Op. O.L.C 6, 7 (1992). 
In this bizarre circularity, sending the military can be justified as safeguarding the military already sent. Nowhere in the legal rationale was war or Congress so much as mentioned.

In 1994, the Clinton administration claimed that sending 20,000 troops to Haiti to secure regime change did not constitute war. ${ }^{72}$ The following year, Clinton presided over nearly three months of bombing of Kosovo, ${ }^{73}$ likening it to maintaining troops in Europe and Korea and justifying the action as "in support of an agreement the warring parties have reached and is at the invitation of those parties," 74 as if at least one of the parties had asked to be bombed. The Obama administration oversaw armed drone attacks that killed almost 2,600 persons, excluding persons in Afghanistan, Iraq, and Syria - were these acts of war? ${ }^{75}$ The President's position was that "determining whether a particular planned engagement constitutes a 'war' for constitutional purposes ... requires a fact-specific assessment of the 'anticipated nature, scope, and duration' of the planned military operations [involving] prolonged and substantial military engagements." ${ }^{\text {" } 66}$ By this "fact-specific assessment," neither deploying troops to achieve regime change in Haiti nor flying over 2,300 sorties over Bosnia qualified as wars. ${ }^{77}$

President Obama bombed Libya's air defenses and provided logistical support for NATO airstrikes in 2011, in an effort to secure regime change. The Libyan campaign consumed over a billion dollars, continued for six months, and contributed to overthrowing a government and murdering its leader, but the administration maintained, "We're not engaged in sustained fighting. There's been no exchange of fire with hostile forces. We don't have troops on the ground. We don't risk casualties to these troops." 78 Two years later, Obama threatened to intervene in Syria over the regime's use of poison gas against civilians. Though he later said that he would seek congressional authorization before acting, he continued to claim that

72 Deployment of United States Armed Forces into Haiti, 18 Op. O.L.C. 173, 174 n.1, $178-79$. President George H. W. Bush in 1989 had invaded Panama also to secure regime change. He spoke with congressional leaders, but did not seek congressional authorization. 2 Pub. Papers of George Bush 1722-23 (1990).

73 Richard B. Bilder, Kosovo and the "New interventionism" Promise or Peril? 9 J. TRANSNAT'L L. \& Pol'y 153 (1999); Michael Hahn, The Conflict in Kosovo: Almost War? 89 Geo. L.J. 251 (2001).

74 Walter Dellinger, Proposed Deployment of United States Armed Forces into Bosnia, 19 Op. O.L.C 327, 330-32 (1995).

75 Off. Dir. Nat'1. Intel., Summary of Information Regarding U.S. Counterterrorism Strikes Outside Areas of Active Hostilities (Jan. 19, 2017), https://www.dni.gov/index.php/ newsroom/reports-publications/reports-publications-2017/item/1741-summary-ofinformation-regarding-u-s-counterterrorism-strikes-outside-areas-of-active-hostilities.

76 Caroline D. Krass, Authority to Use Military Force in Libya, 35 Op. O.L.C 1, 8 (2011).

77 Regarding Bosnia, each house of Congress adopted resolutions supporting the troops, but expressing reservations about the mission. S.J. Res. 44, 104th Cong. (1995) and H.R.J. Res. 302, 104th Cong. (1995).

78 Scott Wilson, Obama Administration: Libya Action Does Not Require Congressional Approval, WaSH. Post, June 15, 2011. Candidate Obama had told an interviewer, "The President does not have power under the Constitution to unilaterally authorize a military attack in a situation that does not involve stopping an actual or imminent threat to the nation... It is always preferable to have the informed consent of Congress prior to any military action." Charlie Savage, Barack Obama’s Q\&A, Boston GloBe, Dec. 20, 2007. 
he had "the authority to carry out this military action without specific congressional authorization." 79

If brief attacks like these should lead to further armed conflict, would the initial attack count as an act of war? As it is impossible to predict with certainty all the consequences of such initial attacks, should they all be termed acts of war? Certainly, George W. Bush could not have anticipated that the wars begun in Iraq and Afghanistan would continue over a decade past his leaving office. As one former Pentagon official put it, "war and peace are not binary opposites, but rather the outer limits of a continuum." fighting on a battlefield has been revised by technology and experience. None of these administrations conceded that it was waging war and, therefore, required congressional assent. Yet a consequence was that it "deprived the country of . . . national debates about the nature of the threat and the proper response," $"$ debates that might have improved decisions, educated the public, enhanced accountability, and encouraged all actors to give serious consideration to the very serious issue at hand.

On the other hand, if each of this wide range of actions required a formal declaration of war, the government would in the first instance often find it difficult to start acting, and in the second instance difficult to stop. Flexibility, commonly advantageous in security matters, would be severely limited. Is it possible, then, that a formal declaration would be required for an all-out war, like World War II, but not for much more limited engagements, like the President Reagan's 1983 invasion of Grenada? ${ }^{82}$ The Correlates of War Project has proposed that wars be defined as armed conflicts with at least a thousand combat deaths, but plainly the number (which may be uncertain and open to manipulation) is arbitrary. ${ }^{83}$ The Falklands War with 907 deaths would not make the cut nor would America's Barbary War during the Jefferson and Madison administrations, where 818 were killed. But if these were not wars, what were they?

Which raises the question as to the relation of declarations of war to war. Obviously, there can be war without a declaration, for the point of surprise attacks would be lost if the attacker first declared an intention to fight. Similarly, there can be a declaration without war, at least for a time, as the seven month "phony war" preceding the German attack on France and Britain in World War II illustrates. In the Middle East, a number of Arab states remain in a state of war with Israel over

79 White House Office of the Press Secretary, Statement by the President on Syria, (Aug. 31, 2013), https://obamawhitehouse.archives.gov/the-press-office/2013/08/31/statementpresident-syria. The threat never culminated in action. Obama was criticized for deferring to Congress, both contemporaneously (e.g., Matthew Pinsker, Obama Fails Lincoln Lesson on Syria, USA Today, Sept. 11, 2013) and later (e.g., Leon PanetTa \& Jim Newton, Worthy Fight: A Memoir of War AND Peace 450 (2014).

80 Rosa Brooks, How Everything Became War and the Military Became Everything 352 (2016).

81 Jack L. Goldsmith, The Terror Presidency: LaW and Judgment Inside the Bush Administration 207 (2007).

82 Michael Rubner, The Reagan Administration, the 1973 War Powers Resolution, and the Invasion of Grenada, 100 PoL. SCI. Q. 627 (1985).

83 Lewis F. Richardson, Statistics of Deadly Quarrels (1960) and J. David Singer \& Melvin Small, The Wages of War, 1816-1965: A Statistical Handbook (1972) also agree on a thousand. 
seventy years after the initial declaration, though actual fighting has taken place only intermittently. The connection of war and declarations of war is not always obvious.

Which highlights a minor irony: as "war" has become commonplace metaphorically - war on drugs, war on crime - it has been displaced in international law by such terms as "armed attack" or "use of force." 84 Thus, a pair of authorities concluded that "declarations of war serve little purpose under international law."

\section{The War Powers Resolution}

Congress has been reluctant to seize major responsibility for initiating armed conflict by formally declaring war. Though the public is invariably enthusiastic at the outset, the longer range prospects are uncertain and a formal declaration would etch congressional support in granite, perhaps leaving members vulnerable at the polls. Yet in order to retain its status and power, Congress can hardly renounce its role in the nation's most important and visible political decisions. Enter the War Powers Resolution of $1973,{ }^{86}$ enacted as a rebuke to President Nixon's unilateral actions in Southeast Asia at a time when he was reeling from Watergate. The purpose of the resolution, according to a Senate report, was "to prevent secret, unauthorized military support activities and to prevent a repetition of the most controversial and regrettable actions in Indochina." 87 The resolution begins by stating that the President may exercise his commander in chief powers only if Congress has declared war or authorized participation by statute or if the nation has been attacked, but then undermines this principle by announcing that it will be enough for the President merely to "consult" with Congress before sending troops into hostilities. If he orders military engagement, he must report his action to Congress within forty-eight hours. Unless Congress acts, the troops must be withdrawn after sixty days, though Congress may have him order them out of hostilities at any time. Thus was the declaration of war redefined and the congressional role downsized to merely speaking with leaders.

President Nixon vetoed the resolution, ${ }^{88}$ but weakened by scandal, was unable to block it. Later commentators have often echoed his fear, for example, calling it "dangerous to the country's safety because it denies flexibility to the President ... and conveys a message of potential disunity." ${ }^{89}$ However, the next two Presidents, Ford and Carter, both vulnerable and about to be defeated at the polls, virtually ignored the law and suffered no bad consequences. Ford, unelected and facing a Democratic Congress, met the reporting requirement in evacuations from

\footnotetext{
U.N. Charter, art. 2.

Curtis A. Bradley \& Jack L. Goldsmith, Congressional Authorization and the War on Terror, 118 HaRv. L. REv. 2048, 2061 (2005).

86 War Powers Resolution Nov. 7, 1973, Pub. L. 93-148, 87 Stat. 555.

87 S. Rep. No. 93-220, at 24 (1973).

889 Weekly Comp. Pres. Docs. 1285-86 (Oct. 24, 1973).

89 J. Terry Emerson, Making War without a Declaration, 17 J. Legis. 23, 51 (1991).
} 
Vietnam and Cambodia ${ }^{90}$ and the retaking of a freighter, the Mayaguez, ${ }^{91}$ seized by Cambodia, but failed to consult with Congress. ${ }^{92}$ Carter, weakened by economic stagflation and the humiliation of Iran's holding diplomats hostage, refused to consult with Congress prior to his failed hostage raid; the War Powers Resolution provides for consultation "in every possible instance," he argued, but a fear that it might compromise the secrecy of the mission and its element of surprise meant that this was not a "possible instance." ${ }^{93}$ He was pilloried after the raid, not because he failed to consult with Congress but because the raid was a fiasco. ${ }^{94}$

When President Reagan dispatched 1,900 Marines and Army Rangers to Grenada to protect American civilians in the aftermath of a bloody coup, he consulted with congressional leaders only after the invasion order was given..$^{95}$ House Speaker Thomas P. “Tip" O’Neil reported that “we weren't asked for advice," but were only "informed what was taking place," ${ }^{96}$ but far from complaining, he said to Reagan, "God bless you, Mr. President. And good luck." ${ }^{\prime 97}$ Nor did George H.W. Bush consult before sending troops to capture the president of Panama. ${ }^{98}$

In 2017, President Trump authorized "bloodying the nose" of Syria, which had used poison gas against civilians, by sending fifty-nine cruise missiles to strike Syrian military targets, solely on his own authority. ${ }^{99}$ A year later, rejecting

90 War Powers Act: Test of Compliance, Hearing before H. Comm. on International Relations, at $9,30,41,94^{\text {th }}$ Cong., $\left(1^{\text {st }}\right.$ sess. 1975). However, the ultimate collapse of South Vietnam was precipitated by congressional action, namely, the refusal to fund the war.

91 Roy Rowan, The Four Days of MaYaguez 179-80 (1975). Ford also deployed troops on rescue missions to Cyprus and Lebanon and did not report to Congress.

92 Ford wrote that he "did not concede that the resolution itself was legally binding on the President on constitutional grounds." W. TAYlor Reveley III, War Powers of the President and Congress: Who Holds the Arrows and Olive Branch? 254 (1981).

93 Lloyd Cutler, Legal Opinion on War Powers Consultation Relative to the Iran Rescue Mission, May 9, 1980.

94 Initially, a few Senators, including Frank Church (D-ID) and Charles Mathias (R-MD), criticized Carter for ignoring the War Powers Resolution, but this was very short lived, as Congress focused attention on why the helicopters used malfunctioned. Steve Delaney, Congress Reacts to President Carter's Rescue Mission to Iran (NBC Nightly News Apr. 11, 1980). In his televised address to the nation after the raid, Carter offered no legal justification for the mission. Address to the Nation on the Rescue Attempt for American Hostages in Iran (NBC Nightly News Apr. 25, 1980.) On the mission, see Mark Bowden, The Desert One Debacle, The AtLantic, May, 2006.

95 Michael Rubner, The Reagan Administration, the 1973 War Powers Resolution, and the Invasion of Grenada, 100 PoL. SCI. Q. 627, 630-36 (1985).

96 Hedrick Smith, 1,900 U.S. Troops, with Caribbean Allies, Invade Grenada and Fight Leftist Units; Moscow Protests; British Are Critical, N.Y. Times, Oct. 26, 1983, at 1.

97 Ed Magnuson, D-Day in Grenada, Time, Nov. 7, 1983, at 28.

98 Eytan Gilboa, The Panama Invasion: Lessons for the Use of Force in the Post-Cold War Era, 110 PoL. SCI. Q. 539, 558-59 (1995); Eileen Burgin, Congress, the War Powers Resolution, and the Invasion of Panama, 25 POLITY 217 (1992).

99 Charlie Savage, Was Trump's Syria Strike Illegal? Explaining Presidential War Powers, N.Y. Times, Apr. 8, 2017. A few months later, a National Security Council official announced, "The administration is not seeking a new AUMF, as the U.S. has sufficient authority to prosecute the campaign against the Taliban, al-Qaida, and associated forces, including ISIS." John T. Bennett \& Lindsey McPherson, White House Brushes off Calls for Updated Authorization of Military Force, Rollcall (Sep 7, 2017 1:12 PM.), https:// www.rollcall.com/news/politics/92700-2 One scholar, however, took the position that "even 
his defense secretary's call for congressional approval ${ }^{100}$ and facing innumerable scandals, he found that his bombing of chemical warfare sites in Syria provoked little dissent. Though House Speaker Paul Ryan (R-WI) defended the action as justified under the 2001 Authorization for Use of Military Force, ${ }^{101}$ it was so obvious that the statute aimed at 9/11 perpetrators was irrelevant that the President himself spoke only of his generalized "constitutional authority to conduct foreign relations and as commander in chief and chief executive [acting] in the vital national security and foreign policy interests of the United States." ${ }^{102}$ Later, he added that he was "keep[ing] the Congress fully informed, consistent with the War Powers Resolution," 103 but did not indicate that he had consulted with congressional leaders before acting. Nor was there authorization from the UN Security Council. Nor was the United States under attack or an imminent threat of attack from Syria. The administration has declined to make publicly available the legal justification for the attack, though it later conceded that the attorney general was briefed only on the day following the attack, so that he could advise the President in "future attacks."104

President Trump, like President Obama justifying his 2011 airstrikes against Libya, rooted the strikes in the President's reasonably determining that they "serv[ed] important national interests." 105 The only limitation on his power was the requirement that the actions not be "prolonged and substantial military engagements, typically involving exposure of U.S. military personnel to significant risk over a substantial period." ${ }^{106}$ As Presidents will nearly always be able to point to a national interest - why else would they be concerned? — this hurdle does not amount to much of an obstacle.

The ongoing civil war in Yemen illustrates the ongoing nature of the problem. In the civil war, which has produced appalling and widespread civilian suffering and deaths, the United States is not a belligerent, but its secondary role supporting a Saudi coalition by training combatants, providing intelligence, weapon sales, commando raids, and air strikes is of considerable importance. The target is Houthi

low-level uses of force" against another country implicates the declare war clause. Michael Ramsey, The Constitution and Syria (Again), Originalism Blog (Apr. 7, 2017), https:// originalismblog.typepad.com/the-originalism-blog/2017/04/the-constitution-and-syriaagainmichael-ramsey.html.. President Clinton had earlier bloodied the nose of Saddam Hussein, who had tried to assassinate former President Bush. Letter to Congressional Leaders on the Strike on Iraqi Intelligence Headquarters 29 Weekly Comp. Pres. Docs. 1183 (June 28, 1993).

100 Helene Cooper, Mattis Wanted Congressional Approval Before Strikes, N.Y. Times, Apr. 18, 2018.

101 Joe Gould, Key Democrats Want Trump to Hit the Brakes on Syria Strike, Defense News, Apr. 13, $2018 \mathrm{https://www.defensenews.com/congress/2018/04/13/key-democrats-want-}$ trump-to-hit-the-brakes-on-syria-strike/.

102 White House Letter of Notice to the Speaker of the House and the President Pro Tempore of the Senate (Apr. 13, 2018). The President's televised speech to the nation offered no legal justification. White House Office of the Press Secretary, Statement by President Trump on Syria (Apr. 13, 2018) . The Constitution is silent as to the President's powers to act unilaterally in support of vital national security and foreign policy interests.

103 Id.

104 Second Declaration of Paul P. Colborn at 3, The Protect Democracy Project v. U.S. Dept. Defense, No.17-cv-00842-CRC (D.D.C. Jan. 9, 2018).

105 Steven A. Engel, 42 Op. O.L.C. 9 (2018).

106 Id., citing Authority to Use Military Force, 35 Op. O.L.C. 8 (2011). 
rebels, supported by Iran but not officially designated as a terrorist group and operating entirely within Yemen. American involvement began under President Obama in 2011 and continues under President Trump. In 2018, it became known that American Special Forces were involved, although such action was denied by the Defense Department and was not authorized by Congress. Senator Tim Kaine (D-VA) called for congressional authorization, but nothing came of it. ${ }^{107}$ The government, for its part, has maintained that the events in Yemen do not constitute hostilities ${ }^{108}$ and that, in any case, they are covered by the 2001 AUMF.

Careful scholars have concluded that "U.S. military forces have not crossed the threshold of direct, imminent involvement in hostilities, under traditional interpretations of the War Powers Resolution," 109 but it is difficult to see how the Saudi-led coalition could have functioned at its current level without American help. Further, the resolution expressly includes under "introduction' of armed forces, "the assignment of . . . armed forces to command, coordinate, participate in the movement of, or accompany the regular or irregular military forces of any foreign country or government when such military forces are engaged, or there exists an imminent threat that will become engaged, in hostilities." 110 The application to Yemen is obvious, and served as the basis for a Senate joint resolution, claiming that the War Powers Resolution compelled Trump to withdraw military forces from the Yemeni war. Never before had the Senate passed a resolution that could expedite action under the War Powers Resolution. ${ }^{111}$ However, as the House refused to take up the issue, no legislation was enacted, and the resolution was exposed as a mere gesture. Democratic victories in the 2018 elections gave them a majority in the House, however, and they responded by voting 243 to 177 to invoke the War Powers Resolution's provision that permits Congress to force the withdrawal of troops, when no formal declaration of war had taken place. ${ }^{112}$ The Senate declined to repass its similar 2018 resolution.

Where, then, did the legal justification for unilateral presidential action come from? The answer is dicta, first in a World War II opinion concerning America training British flying students, ${ }^{113}$ next in an opinion concerning Truman's entry in

107 Helene Cooper, Thomas Gibbons-Neff \& Eric Schmitt, Green Berets Quietly Aid War on Yemen Rebels, N.Y. TIMES, May 4, 2018.

108 Letter from William S. Castle, Acting General Counsel, Dep't of Defense to Senator Mitchell McConnell (Feb. 27, 2018).

109 Oona A. Hathaway et al., Yemen: Is the U.S. Breaking the Law? Harv. Nat'L Security J. (2018).

11050 U.S.C. $\$ 1547$ (c).

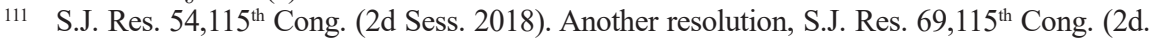
Sess. 2018), called for a diplomatic solution to the Yemen crisis, countering the President's support of the Saudis' military effort.

112 The rebuke to the Saudis reflected not only a growing horror at the civilian cost of the war, but also outrage at the murder and dismemberment of Jamal Khashoggi, a Saudi activist living in the United States, which inflamed American public opinion.

113 Robert Jackson, Training of British Flying Students in the United States, 40 Op. Att'y Gen. 58 (1949). 
the Korean War, ${ }^{114}$ and then in United States v. Verdugo-Urquidez. ${ }^{115}$ From these dicta, the Office of Legal Counsel, in a 1992 opinion on intervention in Somalia, concluded "that the President has the power to commit United States troops abroad for the purpose of protecting important national interests." 116 Two years later, this finding buttressed an OLC opinion on intervention in Bosnia and Herzegovina. ${ }^{117}$ Thus did dicta, unmoored to constitutional text, generate doctrine, leaving Presidents free to act militarily whenever they thought it useful. ${ }^{118}$ The subsequent "legitimacy" of Trump's Syrian bombing ${ }^{119}$ was tethered only very weakly to the law; the main anchor was moral outrage and disgust over the use of poison gas. ${ }^{120}$

What is interesting is what did not happen: there was no great congressional or public outcry. Of forty-nine Senate Democrats and Independents, only four opposed the strikes and nine raised the issue of congressional authorization but supported the strike; no less than twenty others voiced their support. In the House, opposition was greater but no more effective. Ninety members of both parties called on the President to "consult and receive authorization from Congress before ordering additional use of U.S. military force in Syria," 121 and the Progressive Caucus predicted that "U.S. military interventions will likely add to the mass suffering in Syria." 122 A new AUMF proposed by Senators Corker (R-TN) and Kaine, which claimed to expedite congressional action but actually left presidential discretion intact, ${ }^{123}$ excited very little interest. The congressional and media noise level was

114 Authority of the President to Repel the Attack in Korea, 23 Dep't. St. Bull. 173 (1950). Truman asserted that he could "send troops anywhere in the world," without congressional authorization. Harry S Truman, 7 PUB. PAPERS, 9 (Jan. 11, 1951). Congress acquiesced.

115494 U.S. 259, 273 (1990).

116 Timothy E. Flanagan, Memorandum Opinion for the Att'y Gen. 16 Op. O.L.C. 1 ( Dec 4 1992).

117 Proposed Deployment of United States Armed Forces into Bosnia, 19 Op. O.L.C. 327, 333 (Nov. 30, 1995).

118 A retired Air Force major general defended Trump's second Syria strike as consistent with a developing norm to protect helpless civilians and as anticipatory self-defense, given the 2,000 American soldiers then in Syria. Charlie Dunlap, Yes, There Are Plausible Legal Rationales for the Syria Strikes, LAwFARE (Apr. 19, 2018), https:/www.lawfareblog.com/yes-there-areplausible-legal-rationales-syria-strikes. As the norm has not yet been recognized and the American soldiers had never been targeted, the argument is a bit of a stretch.

119 Nikki Haley, U.S. Mission to the UN, Remarks at an Emergency UN Security Council Meeting on Syria, United States Mission to the United Nations (Apr. 14, 2018), https:// usun.state.gov/highlights/8372.

120 For example, Sen. Rubio (R- FL) spoke of Assad's "war crimes" and Rep. Thornberry (RTX) talked of "future atrocities." Where Top Lawmakers Stand on Syria, N.Y. Times, Apr. 7, 2018.

121 Letter from Rep. Zoe Lofgren to President Trump (D-CA) et al., (Apr. 13, 2018), available at https://lofgren.house.gov/media/press-releases/88-bipartisan-members-urge-congressionalauthorization-military-action-against.

122 Sarah Lazare, Senate Democrats Offer Little-to-No Opposition to Trump's Expansion of Syrian Bombing, In These Times, Apr. 16, 2018.

123 S.J. Res. II, 115 Cong. (2d sess. 2018) While replacing the 2001 and 2002 AUMFs, it would have guaranteed uninterrupted authority for the 2001 AUMF (thereby approving ongoing operations) and would have granted the President authority to identify associated groups, provided only that he informs Congress within forty-eight hours. In place of a sunset clause, it would have merely required that he report to Congress activities undertaken pursuant to the law every four years. Transparency would have marginally improved. 
muted, and in a few days, like news coverage of a train accident, debate over the bombing was over. Was this because the Syrian government was so reviled that the complaints might strike voters as little more than a turf battle? But turf battles, sometimes called "checks and balances," are foundational constitutionally. Or was it because the President was under attack from so many fronts that his bombing decision simply got lost? But bombing presumably is too important to overlook. Or was it that presidential dominance in the Yoo mode was so well established that the affair seemed far more familiar than aberrant?

The lesson was plain: presented as a means of strengthening Congress and opposed by Presidents as intruding into their prerogatives, the War Powers Resolution has worked to free the President from constitutional strictures, granting him unilateral powers in excess of those expressed in the Constitution and compounding the confusion by leaving the meaning of key terms like "hostilities" and "consultation" unclear. However, even if "consultation" were construed as "seeking advice or opinions," how to ensure that the advice or opinions are taken seriously? In sum, the most obvious factor explaining the weakness of the resolution is simply that Congress has declined to enforce it. ${ }^{124}$ Any worry that the resolution would seriously weaken presidential discretion is misplaced.

Three years after the War Powers Resolution was passed, Congress adopted the National Emergencies Act, ${ }^{125}$ which brings together other emergency law statutes and mimics the declare war clause, in requiring that the President officially announce a national emergency in order to access the power. Congress may override the declaration, but the override in turn would be subject to a presidential veto. Still, it is not the emergency that justifies presidential action, but rather Congress' acquiescence.

Of course, Congress may question whether an actual emergency exists, but this will not be easy because the statute never defines the term and because past practice would seem to grant the President virtually unlimited discretion. ${ }^{126}$ Congress has formally and informally delegated so much discretion to the President for so many years that a strong act of will would be required to halt the momentum. Congress' checking power under the statute has never been exercised.

124 Relevant international agreements do not appear to have had much impact. The KelloggBriand Peace Pact (1928), for example, "condemn[ed] recourse to war for the solution of international controversies and renounce[d] it as an instrument of national policy in their relations with one another." Art. I, Treaty Providing for the Renunciation of War as an Instrument of National Policy, 46 Stat. 2343 (1929). Most authorities regard it as ineffective. See, e.g., Stephen M. Walt, There's Still No Reason to Think the Kellogg-Briand Pact Accomplished Anything, Foreign Policy (Sept. 29, 2017, 7:00 AM ), https://foreignpolicy. com/2017/09/29/theres-still-no-reason-to-think-the-kellogg-briand-pact-accomplishedanything/. But cf., OONA A. HathaWAY \& SCOTt J. Shapiro, The InTERnATIONALiSTS: How a Radical Plan to Outlaw War Remade the World (2017), where it is argued that the pact upset the "classical international law" assumptions that nations possessed the right to wage wars to rectify wrongs and if successful, could seize territory or funds from the losers.

125 50 U.S.C. $\$ 1601-1651$, Pub. L. 94-412, 90 Stat. 1255 (1976).

126 For example, President Clinton announced an emergency, prohibiting new investment in Burma (E.O. 13047, 1997); President George W. Bush, blocking property of Balkan terrorists (E.O. 13219, 2001); and President Obama, blocking property of Central African Republic fighters (E.O. 13536, 2010). 


\section{The Gulf of Tonkin Resolution}

The President has always had options other than a formal declaration of war, and two episodes, one before the enactment of the War Powers Resolution, the Gulf of Tonkin crisis, and one after, the war on terror's Authorization for Use of Military Force, illustrate what forms this may take.

Consider the Gulf of Tonkin crisis during the Vietnam War. In 1964, the position of the South Vietnamese government was deteriorating to the point that July "was the bloodiest [month] of the war up to that time." 27 In response, the government increased its commando raids against the North, and by the end of the month the North had complained to the International Control Commission about an attack on a fishing boat in the Gulf of Tonkin, where an American destroyer, the Maddox, was alleged to have provided protection for South Vietnamese patrol boats. But though an air of high tension was enveloping the South, American public opinion was paying little attention to these developments.

On August 2, according to Secretary of Defense Robert McNamara, three North Vietnamese torpedo boats attacked the Maddox in the Gulf. "The Maddox was operating in international waters," he said, on a "routine patrol," and had been engaged in no provocative actions. ${ }^{128}$ Hanoi admitted that its boats had attacked, claiming that the Maddox had violated its coastal waters and had shelled its islands. American planes, dispatched from a nearby aircraft carrier, sunk one of the North Vietnamese boats and damaged three others. President Johnson warned North Vietnam that "grave consequences" would follow if the attacks were repeated, ${ }^{129}$ and sent a second destroyer, the C. Turner Joy, to join the Maddox in a patrol near two North Vietnam islands that had been attacked a few days earlier. On August 4, the administration reported, the two destroyers had been fired on by torpedoes, which they evaded. They responded by sinking two patrol boats. This time, North Vietnam denied that any attack had taken place.

President Johnson convened the National Security Council for one of its rare meetings, and at his instigation it recommended retaliation. The President then sent sixty-four bombing missions against the North and made a series of long range military moves to increase America's presence in the area. With his top Pentagon and State Department officials, he also met with leaders of Congress, seeking a resolution "making it clear that our government is united in its determination to take all necessary measures in support of freedom and in defense of peace in Southeast Asia." 130 None of the congressional leaders objected. That evening, in a televised address to the nation, the President defended the air strikes and the

127 Kenneth Sams, Air Power - the Decisive Element, 49 AIr Force SPACE Digest 49 (Mar. 1966).

128 South East Asia Resolution, Joint Hearing before S.Committees on Foreign Relations and on Armed Forces, on Joint Resolution to Promote Maintenance of International Peace and Security in Southeast Asia, 88 Cong. (2d sess. Aug. 6, 1964) Copies of the transcript were not released until Thanksgiving Day 1966, and testimony on whether raids had provoked the attacks were censored.

129 Lyndon B. Johnson, U.S. Protest to North Vietnam, (Aug. 3, 1964), 51 Dept. State Bull. 258 (Aug. 24, 1964).

130 Lyndon B. Johnson, Address of the President, Syracuse University (Aug. 5 1964), 51 Dept. State Bull. 260 (Aug. 24, 1964). 
resolution. The next day, he repeated this position in a widely reported speech, and was supported in appearances by the Secretary of State and the United Nations Ambassador. Newspapers were nearly all laudatory. ${ }^{131}$ Public opinion favored the resolution, ${ }^{132}$ and became sharply optimistic following the Gulf events. A tepid July 21 poll revealed that thirty-nine percent of the public thought the war was going as well as could be expected and forty-one percent thought it was going badly; by August 4, the percentages had changed to seventy-two and sixteen, respectively. ${ }^{133}$

On August 6, the President formally asked Congress for a joint resolution, requesting its full support "for all necessary action to protect our armed forces and to assist nations covered by the SEATO treaty." 134 After brief closed door hearings and little floor debate, the resolution was approved on August 7, 416-0 in the House and 88-2 in the Senate. ${ }^{135}$ By the winter, bombing of the North was well underway, and by the end of 1965, troop strength had increased from 23,000 to 184,000. The resolution would before long, in the words of the Under Secretary of State, "fully fulfill the obligation of the Executive in a situation of this kind to give the Congress a full and effective voice, the functional equivalent of the constitutional obligation expressed in the provision of the Constitution with respect to declaring war." ${ }^{136}$ As the functional equivalent of a declaration of war against the North, the resolution in the short term was used to rebut charges by Senator Barry Goldwater (R-AZ), Johnson's rival for the presidency, to the effect that he was insufficiently tough in defense matters. In the longer term, it provided congressional authorization for escalating the war.

As time passed, several members of Congress who had backed the resolution began to have serious qualms about the war. In 1967, the Senate Foreign Relations Committee undertook an investigation of the events in the Gulf, and concluded that there had been mass confusion at the Pentagon on the day of the second incident to the extent that it could not even be sure that a second attack had taken place. ${ }^{137}$

131 Support, for example came from the New York Times, the Washington Post, the Philadelphia Inquirer, the Los Angeles Times, the Miami Herald, the Charlotte Observer, and the Richmond Times-Dispatch.

132 For example, a 1964 Survey Research Center poll found that forty-six percent favored escalation and only thirteen percent withdrawal. William L. Lynch \& Peter W. Sperlich, American Public Opinion and the War in Vietnam, 3 West. Pol. Q. 21, 27 (1979).

133 Brian S. Anthony, On Public Opinion in Time of War 11 (Sept. 2009) (unpublished thesis, Naval Postgraduate School), https://apps.dtic.mil/dtic/tr/fulltext/u2/a514232.pdf.

134 Lyndon B. Johnson, President's Message to Congress, 51 Dept. State Bull. 262 (Aug. 24, 1964).

13578 Stat. 384 (1964).

136 Nicholas deB. Katzenbach, quoted in William Conrad Gibbons, The U.S. Constitution and the Vietnam War: Executive and Legislative Relations, Part IV, 813 (1995). In 1967, Katzenbach angrily asked a prominent Senate critic of the war, "didn't that resolution authorize the President to use the armed forces of the United States in whatever was necessary? Didn't it? What could a declaration of war have done that would have given the President more authority and a clear voice of the Congress than this?" United States Commitments to Foreign Powers, Hearing before S. Comm. on Foreign Relations $90^{\text {th }}$ Cong. $81\left(1^{\text {st }}\right.$ sess. 1967). By 1970, Katzenbach was backing an effort to repeal the resolution. John W. Finney, Katzenbach, Who Termed Tonkin Gulf Resolution "Equivalent" of Declaration of War, Now Backs Repeal, N.Y. Times, July 29, 1970.

137 According to a communique from the Naval Communications Center sent about four hours after the supposed attack, "Review of action makes many recorded contacts and torpedoes 
Subsequent testimony cast added doubt on the second attack and portrayed the destroyers as invading the North's territorial waters in provocative ways. Secretary McNamara admitted that, at the time, he had met for about four and a half hours with top military officials, "reviewing the information that bore on whether an attack had taken place." 138

The revelations induced a number of members of Congress to charge angrily that they had been misled. Foremost was J. William Fulbright (D-AR), chair of the Foreign Relations Committee and an old friend of Johnson, who had shepherded the resolution through the Senate. Now, he bitterly turned against Johnson, arguing that the resolution could not be considered the functional equivalent of a declaration of war, "especially having been made under conditions of emergency." 139 The events described to Congress on August 5 were very different from the events as depicted months later. The members felt deceived.

What members of Congress refused to concede was their own complicity in the affair, for what is most striking is that even had the original description been accurate in all particulars, it hardly constituted a crisis calling for an immediate, far reaching response. It was known at the time that no American was killed or wounded. Even property damage was minimal. ${ }^{140}$ But if the Tonkin Gulf incidents did not constitute a crisis, it was clear to the administration that without major American intervention, the war itself might in the coming months pose a crisis - a crisis to the administration's policy, if not to the nation. The faux crisis, in this sense, was a proxy for a true crisis that seemed just beyond the horizon. The administration's response was not a wholesale falsification of facts, but instead an approach more subtle and effective: the creation of an ambience of crisis by appealing to national pride and marketing a narrative full of urgency and outrage. Of course, there is no way to be certain that formal hearings on a declaration of war, then or later, would have produced a different result. But the episode does suggest that available work-arounds like the Tonkin Gulf Resolution, because they are seen as smaller affairs, may be easier for administrations to manipulate than outright declarations. ${ }^{141}$

The Gulf of Tonkin Resolution met the commonly heard goal of the nation's speaking with one voice. But it also suggests how this may lead to folly. With dissent stigmatized as obstructionist, if not unpatriotic, other options were not explored. As vigorous discussion is the heart of democracy and good public policy, its absence may be risky, indeed. The episode also points to the public's belief that war requires a war declaration. President Johnson, the consummate politician of

fired appear doubtful. Freak weather effects and overeager sonar may have accounted for many reports. No actual visual sightings by Maddox. Suggest complete evaluation before any further action." Hearing, supra note 81, at 57. By December the Pentagon had concluded that the second attack was "probably imaginary." JOSEPH C. GOULDEN, TRUTH Is THE FIRST Casualty 208 (1969).

138 South East Asia Resolution, Joint Hearing before S. Committees on Foreign Relations and on Armed Forces, supra note 128, at 58.

139 Id. at 82.

140 It was later said to consist of one bullet hole. Eric Sevareid, Why Our Foreign Policy Is Failing: An Interview with Senator Fulbright, Look, 26, May 3, 1966.

141 The Gulf of Tonkin Resolution was repealed in lopsided votes in 1971, under pressure from the Nixon administration determined to deny anti-war Democrats a legislative victory. 84 Stat. 2053, 2055 (1971). 
his day, fully understood this. Had he pushed Congress for a formal declaration, he would have increased the prominence of the war enormously and redefined his campaign against a Senator Goldwater he had tarred as a warmonger, enraging many of his supporters. But the Tonkin Gulf Resolution was soon hidden in the campaign fog - only to reemerge after the fog, post-election, blew away.

\section{THE AUMF}

Since the time of John Adams and the French crimes at sea, ${ }^{142}$ President Jefferson and the Barbary pirates, ${ }^{143}$ and President Madison and the Dey of Algiers, ${ }^{144}$ Presidents have gone to Congress seeking authorization for use of military force (AUMF). These early AUMFs suggest that the Framers accepted them in lieu of formal war declarations. The AUMF is not precisely the equivalent of a war declaration, which automatically activates a series of statutes that grant the President the authority to seize control of transportation systems, ${ }^{145}$ extend military enlistments, ${ }^{146}$ and so on. But the President can issue a proclamation asserting a national emergency, and this, together with the AUMF, may be used to greatly expand his powers. The increasing weight of legal obligations attached to formal declarations of war has made AUMFs correspondingly attractive, to the point that they now constitute "the new default." 147

The first important modern AUMF occurred in 1955 and was directed against China. President Eisenhower, fearing that China might attack Taiwan (then called Formosa), an American ally, asked Congress to authorize the use of force "for the specific purpose of securing and protecting Formosa." ${ }^{148}$ This made tangible the President's commitment to defend Formosa, while avoiding an inflammatory declaration of war; by seeking congressional approval, he insulated himself against the criticism that had been directed at President Truman over his involvement in the Korean War to the effect that it had been a unilateral decision. Congress backed Eisenhower, a popular President and a highly respected former general, with only three dissenting votes in the House and Senate. Though China later resumed shelling of Formosan forces, no broad scale attack took place; perhaps the deterrent value of the AUMF deserves credit.

Unquestionably, the most famous AUMFs arose out of the 9/11 attacks. President George W. Bush described the attacks as "acts of war," and, after consulting with congressional leaders, submitted an AUMF to Congress that provided "That the President is authorized to use all necessary and appropriate force against those nations, organizations, or persons he determines planned, authorized, committed, or aided the terrorist attacks that took place on September 11, 2001, or harbored such organizations or persons, in order to prevent any future acts of international

\footnotetext{
2 Stat. $561(1798)$.

1 Stat. $129(1802)$.

144 Stat. 230 (1815).

10 U.S.C. $\$ 2644$ (2012).

10 U.S.C. $\$ 519$ (2012).

147 Tanisha M. Fazal, Wars of Law: Unintended Consequences in the Regulation of ARMed Conflict (2018).

148 Pub. L. 84-4, 69 Stat. 7 (1955).
} 
terrorism against the United States by such nations, organizations, or persons."149 The resolution passed the Senate 98-0 and the House 420-1. Floor debates as well as the text made it clear that the resolution was directed solely at those involved with 9/11, and not at terrorism generally. Bush used the AUMF not only to justify war efforts, but also to provide the foundation for military detention ${ }^{150}$ and warrantless surveillance. ${ }^{151}$

In 2002, with the 9/11 trauma still fresh, President Bush sought a second AUMF to be used against Iraq, which he said had acquired weapons of mass destruction. The resolution authorized the President to use the armed forces "as he determines to be necessary and appropriate in order to (1) defend the national security of the United States against the continuing threat posed by Iraq; and (2) enforce all relevant United Nations Security Council resolutions regarding Iraq."152 This resolution, not tied to 9/11, passed the more skeptical Senate 77-23 and House 296-133, the numerous negative votes reflecting the greater distance from 9/11. Neither resolution contained an expiration date.

Years later, the two AUMFs remain the chief legal foundation for the nation's military anti-terrorist efforts, and they are likely to continue to do so. Initially, the targets were Al Qaeda, the organization that carried out the 9/11 attacks, and the Taliban, which controlled Afghanistan and gave Al Qaeda sanctuary and support. But the AUMFs' scope has since been broadened, as Presidents have widened the application of the statutes. The Tonkin Gulf Resolution, whatever its flaws and however tenuous its basis, at least was invoked against its target. AUMFs have proved to be a weapon that can be directed (and have been directed) at a wide range of targets unnamed at the time of their adoption. Congress, ever eager to avoid controversy, has quietly acquiesced. The courts have said almost nothing, with their leading cases instead concerning the relatively narrow issue of detention. ${ }^{153}$

The Obama administration, facing new terror threats in new places, further stretched the law. ${ }^{154}$ In his September 23, 2014 War Powers Resolution letter, the President outlined a series of military and humanitarian deployments in Iraq, including sending 475 armed forces personnel to Iraq, and noted, "It is not possible to know the duration of these deployments and operations." 155 The international terror picture, organizationally and geographically, had changed considerably in the interval since 9/11. Obama did not mention Al Qaeda or the Taliban, who

149 Pub. L. 107-40, 115 Stat. 224 (2001). The AUMF departed from past practice in targeting organizations and persons in addition to nations. The rationale was that terrorists like $\mathrm{Al}$ Qaeda and the Taliban were not nations.

150 Military Order of November 12, 2001: Detention, Treatment, and Trial of Certain NonCitizens in the War against Terrorism, 66 Fed. Reg. 57833 (Nov. 16, 2001).

151 Legal Authorities Supporting the Activities of the National Security Agency Described by the President, (Dep't of Justice Jan. 19, 2006).

152 PuB. L. 107-243, 116 Stat 1498 (2002).

153 Youngstown Sheet \& Tube v. Sawyer, 343 U.S. 579 (1952) supra note 41.

154 More than other recent Presidents, Obama "practically abandon[ed] the article II treaty process," in favor of executive agreements, partly as a result of intense partisan opposition. Jeffrey S. Peake, The Decline of Treaties? Obama, Trump, and the Politics of International Agreements, Clem. U. DePT' of Poli. SCI, (Apr. 6, 2018).

155 Letter from the President, War Powers Resolution Regarding Iraq, White House Office of the Press Secretary (Sept. 23, 2014). 
had been the targets of the 2001 AUMF, but he did mention Syria, which had not been a target of either AUMF. Nonetheless, the two AUMFs were cited as offering statutory authority.

The following year, Obama proposed an AUMF that would repeal the 2002 AUMF and replace it with one directed against the Islamic State and "associated persons or forces." He announced that passage of the new AUMF "would show the world we are united in our resolve to counter the threat posed by ISIL," 156 which had not existed when the earlier AUMFs were adopted. The new AUMF was unusual in setting a three year time limit and in not covering long term, large scale "enduring" ground combat operations. The President may have considered the 2002 AUMF outdated and his proposal moderate with broad appeal, sharing responsibility for the war with Congress and reinforcing his electoral base with a more narrowly targeted and legally based approach. In this he was mistaken. Progressives in his own party thought the vague reference to associated persons could justify a "forever war," 157 suspecting that the sunset clause could be abrogated by extensions and noting that no geographical limits were included in the resolution. On the right, critics were troubled by the sunset clause and the absence of authority to intervene in Syria. "You have a Republican Congress that wants to grant the President more power than he wants for himself," complained Representative Duncan Hunter (D-CA). ${ }^{158}$ In either case, conservatives regarded the proposal as too restrictive on presidential discretion and liberals as too generous, though simple partisanship was also involved. The bill never came up for a vote. This was the only occasion in recent years, when a presidential AUMF request was not adopted.

However, because President Obama continued to insist that he had constitutional and 2001/2002 AUMF authority to act against terrorists, whoever they were and wherever he found them, the defeat had no practical impact. The rationale, entitled "associated forces," was that the AUMF also implicitly targeted organizations linked to Al Qaeda or the Taliban plus attacking nations linked to the United States or its coalition partners. ${ }^{159}$ This expansive reading, which granted the President wide discretion, rendered the authorization he had sought from a new AUMF superfluous. Thus, notwithstanding that the 2001 and 2002 AUMFs failed to target them, Obama used the AUMFs to justify military engagements against Al Shabab in Somalia, the Khorosan in Syria, and Al Qaeda in the Arabian Peninsula in Yemen, ${ }^{160}$ as well the Islamic State, even if the groups had become rivals and not partners. ${ }^{161}$ Despite the 2015 AUMF failure, Obama oversaw an impressive expansion of presidential authority.

156 Letter from the President, Authorization for the Use of United States Armed Forces in Connection with the Islamic State of Iraq and the Levant, White House Office of the Press Secretary (Feb. 11, 2015).

157 Ryan Goodman, Obama's Forever War Starts Now, Foreign Policy, Feb. 12, 2015.

158 Austin Wright \& Bryan Bender, Authorization for Military Force Stalls, Politico, Mar. 18, 2015.

159 Respondents' Memorandum Regarding the Government's Detention Authority Relative to Detainees Held at Guantanamo Bay at 2, In re Guantanamo Bay Litigation, Misc. No. 08442 (TFH) (D.D.C. Mar. 13, 2009).

160 Charlie Savage, Power Wars: Inside Obama's Post-9/11 Presidency 224-27, 274-79 (2015); Charlie Savage, Is the U.S. Now at War with Shabab? Not Exactly, N.Y. Times, Mar. $15,2016$.

161 SAVAGe, Power Wars, supra note 160 at 688-89. 
Even AUMFs with the explicit goal of "mak[ing] Congress do its job"162 in practice enhance the presidency. The proposed Corker-Kaine AUMF of 2018, ${ }^{163}$ for instance, would have replaced the 2001 and 2002 AUMFs, authorizing the President to designate groups and individuals as "associated forces" to be militarily targeted, provided only that he inform Congress. The resolution failed, but that it was offered by two of President Trump's most prominent national security critics illustrates how reluctant to exercise power Congress really is.

\section{The Threats of President Trump}

So, could President Trump unilaterally order an attack on, say, North Korea? The first thing to say is that it was simply talk, bellicose talk, to be sure, personally insulting talk as well, but simply talk. In more talk a year later, the President announced that "we fell in love, OK? No, really. He wrote me beautiful letters, and they're great letters. We fell in love." 164 But even if his earlier talk pointed to a club in the closet, there is no constitutional prohibition of presidential threats (though article 2 (4) of the United Nations Charter bans states from threatening the use of force). Indeed, the deterrence model, ${ }^{165}$ which dominated the Cold War and continues in force to this day, is built on threat; the chief American nuclear strategic controversies were whether the United States should have first or second strike capabilities ${ }^{166}$ or whether weapons should be aimed at military targets ${ }^{167}$ or population centers, too. ${ }^{168}$ Apart from those favoring nuclear disarmament, everyone took the legitimacy of threat for granted. Certainly, today when the United States joins with South Korea for annual war games, North Korea does not fail to see the element of threat. In a 1950 press conference during the Korean War, President Truman repeatedly said that use of atomic bombs was "under active consideration," 169 an obvious threat. In short, the use of military threats by Presidents is a major theme in recent history. Much of what diplomats and generals do involves signaling to adversaries their willingness to take certain steps, and President Trump may well believe that his threats will incentivize North Korea to agree to a deal that he can live with. In this regard, he may have conceived his warnings as constituting a conditional declaration of war: If these nations fail to meet certain conditions, he may order attacks. ${ }^{170}$ Of course, credible threats will be more effective than those with weak

162 Sen. Tim Kaine (D-VA), quoted in Karoun Demirjun, Senators Release Bipartisan Proposal to Reauthorize Use of Force, WAsh. Post, Apr. 16, 2018.

163 Supra note 123.

164 Fred Kaplan, Trump Said What About Kim-Jung-Un? SLaTe, (Sept. 30, 2018, 3.06PM), https://slate.com/news-and-politics/2018/09/trump-loves-kim-really.html.

165 Richard Sisk, "First Strike" Nuclear Doctrine Won't Change: Carter, Military.com (Sept. 27, 2016) https://www.military.com/daily-news/2016/09/27/first-strike-nuclear-doctrinewont-change-carter.html.

166 See Albert Wohlstetter, The Balance of Terror, 37 For. Afr. 211 (1958); Thomas C. SChelling, Surprise AtTACK and Disarmament, (P-1574) (Rand Corp. 1958).

167 See Walter Slocombe, The Countervailing Strategy, 5 InT'L SECURITY 18 (1981).

168 See e.g., McGeorge Bundy, To Cap the Volcano, 48 For. Afr. 1 (1969).

169 The President's News Conference, supra note 111 (Nov. 30, 1950).

170 President George W. Bush issued an explicit conditional declaration of war to Saddam Hussein in 2002. 
credibility, and if a threat is constitutional, this may add to its credibility, though probably only very modestly.

But if threats helped to prevent warfare between Cold War superpowers, ${ }^{171}$ obviously threats have not always had such benign results. In World War I, for example, Austria-Hungary's threats to Serbia seem to have helped bring on the war, with consequences no one foresaw. ${ }^{172}$ There are threats and there are threats. Some are serious; some are not. Some concern vital interests; some do not. Some are deliberately disrespectful; some observe the usual diplomatic courtesies.

Imagine, then, that President Trump's threats fail to achieve their goal, and he decides on his own and without input from Congress to launch an attack on North Korea. ${ }^{173}$ The Framers certainly agreed that in an emergency, a President could act on his own to respond to an invasion or rebellion, Madison and Elbridge Gerry, for instance, saying that they would leave "to the executive the power to repel sudden attacks." 174 With time pressures vastly greater today-a North Korean missile could hit America in an hour and a half, while in the Framers' time, it would take a ship from Europe at least three weeks to reach American shores - no one doubts that this exception remains viable. In the Caroline incident of 1842, Secretary of State Daniel Webster argued that a pre-emptive attack would be justified only when the need to respond is "instant, overwhelming, and leaves no choice of means, and no moment of deliberation." ${ }^{175}$ This remains the classic justification for pre-emptive attacks. ${ }^{176}$ Webster also emphasized the importance of proportionality, maintaining that any attack must be "justified by the necessity of self-defense, must be limited by that necessity, and kept clearly within it." The UN Charter acknowledges "the inherent right of individual or collective self-defense if an armed attack occurs against a member of the United Nations, until the Security Council has taken measures to maintain international peace and security." 177 One reading would ban any pre-emptive attack; another would claim that the customary right of selfdefense remains unimpaired. But insisting that the President must wait until the last moment to respond to a threat will strike many as reckless and unworkable, for by waiting this long, preferable options might well have been foreclosed.

171 See John E. Mueller, Atomic ObSession: Nuclear Alarmism from Hiroshima to AlQAEDA (2009).

172 Samuel R. Williamson Jr., Austria-Hungary and the Origins of the First World War (1991); Ruth Henig, The Origins of the First World War, ch. 1 (3d ed. 1989).

173 A unique complicating factor is that, technically, a state of war with North Korea still exists, providing the President with an opportunity to claim that an attack would not initiate a new war, but merely resume an old one. It is not clear that this argument would succeed: there has been no fighting since 1953, and in 1950 President Truman was careful to call it a "police action" not requiring prior congressional authorization and not a war.

1742 The ReCORDS OF THE Federal Convention, supra note 14, at 318.

175 Letter from Secretary of State Daniel Webster to British Minister to the United States, Lord Alexander Baring Ashburton (Aug 6, 1842); see also John Bassett Moore, A Digest of INTERNATIONAL LAW 412 (1906).

176 R.Y. Jennings, The Caroline and McLeod Cases, 32 Am. J. InT'L. L 82, 92 (1938). See also Oscar Schacter, The Right of States to Use Armed Force, 82 Mich. L. Rev. 1620, 1635 (1984); Michael Byers, Terrorism, the Use of Force and International Law after 11 September, 51 InT'L \& Comp. L. Q. 401 (2002). But cf. Maria Benvenuta Occelli, Sinking the Caroline: Why the Caroline Doctrine's Restrictions on Self-Defense Should Not Be Regarded as Customary International Law, 4 SAN Diego InT'L L.J. 467, 475-79 (2003).

177 U.N. Charter, art. 51. 
The War Powers Resolution, however, permits the President to circumvent the issue of declaring war. All he would need do is to meet with congressional leaders and file a report, and he would receive a sixty day bye, which he could renew for an additional thirty days.

Conceptually, the time element will be central. If the President acts when there is still the opportunity for diplomatic and political means to succeed and avoid war, he may have denied Congress the deliberative opportunity it needs; an avoidable war will not be avoided. Yet if he waits too long, he may court disaster. And only in hindsight (and not always then) do we know how long is too long. In 1981, Israel destroyed Iraq's Osirak nuclear reactor. It was not yet operational, but Israel was afraid that if it waited until it was producing weapon grade material that might be used in bombs potentially directed at Israel, it would have waited too long. Perhaps some material might already have been created, unbeknownst to the Israelis, that could be weaponized; in any case, waiting and then destroying an operational reactor would risk mass nuclear contamination. ${ }^{178} \mathrm{Or}$, more famously, consider the Soviet effort to install missiles in Cuba. While the installation may have made the American homeland more vulnerable to a nuclear attack, no one suggested that such an attack was imminent. In fact, the imminent danger was brought about not by the Soviet action, but by President Kennedy's response to it. ${ }^{179}$ Similarly, when President George W. Bush invaded Iraq in 2003, it was not threatening the United States, but the invasion itself raised the possibility that it might use weapons of mass destruction (which it later turned out it did not possess). Presidential action addressing an ostensible crisis may bring about an actual or potential one. By this point in 2003, consideration of the time element, supposedly central, had simply vanished.

More fundamentally, what is to be the locus of the decision to go to war? It may well be that Presidents cannot be trusted, that they cannot be counted on to disentangle personal and national interests, that they may cynically seek to create a sense of emergency when they know quite well that no emergency exists. Democracy teaches us to mistrust our rulers, so that we are always ready to throw them out of office. But if not the President, who? Certainly not Congress, with its 535 members.

\section{CRISES}

Who has not experienced terror and the fear of death, only to awaken safely in bed? Or, on the contrary, who has not heard of someone driving routinely, perhaps day dreaming or listening to music, only to be struck suddenly by an unseen speeding vehicle? Crises are not announced in sonorous tones by a celestial butler, but instead are labels officials (and others) impose on events. We may accept an abstract definition, like a serious threat to a high priority goal that requires an urgent response, but its application dissolves consensus. Serious, but how serious? As terrible as 9/11 was, it did not threaten the survival of the nation. But if 9/11 could not qualify as "serious," what could? Who now

178 The UN Security Council unanimously condemned the attack, though plainly several members were quietly relieved at its success.

179 Thomas Halper, Foreign Policy Crises: Appearance and Reality in Decision Making, ch. 6 (1971). 
regards preventing North Vietnam from conquering South Vietnam as serious enough to constitute a crisis? More generally, is preserving credibility a high priority goal? The importance of appearances and expectations should not be underestimated. Yet proclaiming a credibility issue embodies a certain circularity: by pronouncing that our credibility is at stake, we make our credibility at stake. It also runs the risk of elevating a passing slight to a cosmic level, where face saving compromises may be hard to accept. An urgent response? Delay may suggest indecision and embolden adversaries, but stepping back and weighing consequences and alternatives may prove a wise investment. He who hesitates is lost, but sometimes it makes sense to look before you leap.

In the world of international politics, leaders may mistake something else for a crisis or mistake a crisis for something else. Events move swiftly, information is radically incomplete and imperfect, psychological factors like confirmation bias, loss aversion, or reference dependence may warp perceptions, personal careers and national goals may be on the line, personalities and temperaments will generate conflict. Intelligent, experienced, reasonable persons doing their best will make mistakes. And, of course, leaders will not always be intelligent, experienced, reasonable persons doing their best. Recall Cicero's maxim that the safety of the people is the highest law. ${ }^{180}$ Can we take the President's word that the safety of the people is truly in peril?

Civil law systems that trace their lineage to the Roman Republic generally say Yes. For the most part, they explicitly incorporate war and emergency powers in their constitutions, following the Roman example, where consuls with the approval of the Senate could appoint dictators for a six month term, with the dictators dependent upon the Senate for funding. ${ }^{181}$ Article 48 of the Weimar constitution permitted the president in time of emergency to rule by decree, without the approval of the Reichstag, ${ }^{182}$ and article 16 of the constitution of the French Fifth Republic permits the President to declare a state of siege " $[w]$ hen the institutions of the Republic, the independence of the Nation, the integrity of the territory or the compliance with its international commitments are threatened in a serious and immediate manner and regular operation of the constitutional public authorities is interrupted." 183 The constitution does not, however, address the President's powers, except to provide that he "shall take the measures required by these circumstances." In this, the French followed the path of the ancient Roman Republic.

The United States Constitution, like most common law systems, includes no comparable provision, perhaps implying more skepticism as to the virtues of leadership. Indeed, we can imagine a casual reader echoing the view of a modern theorist that "bringing emergencies into the law contaminates the law itself by making it accommodate practices that will of necessity spoil the law." ${ }^{184}$ It is certainly true that the Constitution's war declaration requirement is intended to serve, as a great

180 Cicero, De Legibus, 3.8. (James E.G. Zetzel ed. \& trans. 1990)

181 Clinton W. Keyes, The Constitutional Position of the Roman Dictatorship, 14 StUd. IN Philology 298 (1917).

182 This article provided Hitler with a legal rationale for his seizure of power and the constitutional dictatorship that followed. Clinton Rossiter, Article 48 in Law and Theory, in Constitutional Dictatorship: Crisis Government in Modern Democracies ch. 5 (Clinton Rossiter ed. 2002).

183 Article 36 limits the state of siege to twelve days, unless approved by Parliament.

184 Giorgio Agamben, State of Exception, 32-33 (Kevin Attell trans. 2005). 
scholar remarked in a slightly different context, as "an invitation to struggle," 185 that is, one of the numerous checks and balances built into the system. And the ambiguities of the clause (and the much later War Powers Act), by promoting turf battles, might seem to ensure that no single branch would establish dominance, preventing spoilage of the law. Shifting exigencies generate patterns of conduct that modify or even reverse the text. In foreign affairs, the key rhetorical gambit is often the evocation of crisis. Apart from a mention regarding the suspension of habeas corpus, ${ }^{186}$ the Constitution is silent on the subject of crises. But if the safety of the people is the highest law, ${ }^{187}$ then the power to designate situations as crises is central. For crises enormously expand presidential discretion and, relatedly, are seen as essential to the presidential greatness that egos may crave.

\section{CONCLUSIONS}

For the declare war clause to work, the actors, Congress and the President, must be willing to struggle. The evidence is overwhelming, however, that Congress, invariably opportunistic, is ordinarily unwilling to enter the fray. When the President is popular, struggle is the last thing on its mind. As a consequence, the Framers' insistence that Congress be key in initiating American involvement in war has been repealed by events - and by Congress' own persistent reluctance. When war or, indeed, any military action, is imminent, there is normally an enormous public demand for leadership, which can come only from the President, and in the exhilarating early stage, he typically becomes very popular. Tied to this is the widespread conviction that the end of victory justifies nearly any means (as Hughes put it, "the power to wage war implies the power to wage war successfully") ${ }^{188}$ which quickly translates into an unspoken license to expand presidential powers within limits that are broad, indefinite, and shifting. ${ }^{189}$ In such circumstances, Presidents will likely find irresistible pressures and incentives urging them on to ever more vigorous leadership. Congress, shoved to the background by events, will be aware that leadership is not its role and, in fact, with hundreds of members, is

185 Edward S. Corwin, the President: Office and Powers, 201 (2d ed. 1941). He was referring to foreign affairs, but the observation applies equally to war powers.

186 U.S. CONST. art. $1, \S 9$.

187 Supra note 180. This principle was also applied by the Court in the domestic crisis of the Great Depression. A Minnesota statute permitted persons unable to make their mortgage payments to petition a court to be granted a moratorium on payments; the mortgage holder challenged the statute as violating the Constitution's ban on impairing the obligation of contracts (art. I, sec. 10); the Court, though proclaiming that "Emergency does not create power," held that "[a]n emergency existed . . . which furnished a proper occasion for the exercise of the reserved power of the State to protect the vital interests of the community." Home Building \& Loan Ass'n v. Blaisdell, 290 U.S. 398, 426, 444 (1934).

188 Charles E. Hughes, War Powers Under the Constitution, 40 AnN. ReP. A.B.A. 232, 238 (1917).

189 Lincoln provided a classic rationale. "[O]ften a limb must be amputated to save a life, but a life is never wisely given to save a limb. I felt that measures, otherwise unconstitutional, might become lawful, by becoming indispensable to the preservation of the constitution, through the preservation of the union." Letter to Albert G. Hodges Apr. 4, 1864, 7 THE COLlected Works of Abraham LinCOln supra note 7, at 282. 
simply not possible. It is literally a supporting player, and by supporting the war, it is seen as supporting the country, though it is simultaneously also supporting the President.

We are used to assuming that politicians reflexively seek to extend their power, but in the question of whether to go to war, members of Congress understand that there will be plenty of time later to revise their views, maybe qualifying or even, like Senator Fulbright, withdrawing their support. If the war turns out to be popular, they can claim they supported it; if unpopular, they can call it the President's war and distance themselves from it, in an extreme case even ending it, as they did with Vietnam. But during that very early stage, it is the President's show. Credit and blame, rather than policy or constitutional concerns, tend to drive congressional rhetoric. So powerful are the incentives that even when the facts presented clearly fail to constitute a crisis (Gulf of Tonkin resolution) or the enemy poses no imminent threat (the Houthis in Yemen), the President prevails with ease. Congress may declare war explicitly or implicitly, but in either case, tends to be supine before the President. The view that "Congress' reluctance to issue a formal declaration of war since World War II reflects a domestic concern over the aggregation of power in the executive branch" 190 gets things precisely backwards. The political trumps the constitutional.

Of course, Congress would not abrogate its responsibility if the voters demanded it to act. But though over three-quarters of Americans report thinking it "too risky" to give Presidents more power, ${ }^{191}$ the public has acquiesced quietly to this development, perhaps regarding it as natural, unavoidable or desirable. Congressional refusal to fund the Vietnam War is frequently raised as an illustration of legislative power. But when one recalls that it followed after nearly 60,000 American deaths, over 150,000 wounded, hundreds of billions of dollars spent, and countless protests and demonstrations, it seems like a very tardy arrival at the fair. Indeed, had the presidency not been so weakened by a scandal quite unrelated to the war powers, it is doubtful funding would have been cut off at all. The public wants leadership, often irrespective of its direction, and two legislative chambers with 535 talkative, egotistical members cannot provide it. Congress' role has tended, especially at the beginning, to be cheerleading.

A formal declaration of war, whether following a fabricated crisis (like the Gulf of Tonkin incident) or a national trauma (like 9/11), seems to strike both the President and Congress as ill advised. For it may add pressure to achieve victory when only compromise turns out to be realistic, raising hopes and expectations that cannot be fulfilled; it may make it more difficult to de-escalate or withdraw because the initial commitment was so great; and it may have legal consequences, domestic and international, that may not be helpful. Probably the biggest impact flowing from a declaration would result simply from its not having been invoked for three-quarters of a century. This would set it apart from the far more common

190 Sidak, supra note $15,94$.

191 Carroll Doherty, Key Findings on Americans' Views of the U.S. Political System and Democracy, Pew Research Center (Apr. 26, 2018). At the same time, a Lawfare poll indicated slightly more confidence in the President's ability to protect national security than Congress'. Mieke Eoyang et al., Confidence in Government on National Security Matters: April 2018, LawFAre (Tuesday, May 8, 2018, 2:31 PM), https://www.lawfareblog.com/ confidence-government-national-security-matters-april-2018. 
AUMFs, identify the crisis as greater than and different from more recent crises, and generate immense visibility. But it would be the rarity of the declaration rather than the declaration itself that likely would be responsible for the elevated impact. Put differently, the distinctive consequences flowing from the declaration would mainly be a function of its past disuse, as if it were an inconvenient legal technicality of trifling practical value.

Disuse, in other words, is taken as evidence that the war declaration clause is merely a tired anachronism, a kind of legal vermiform appendix. But this view is hard to sustain. It is true, of course, that international events move much faster today than in 1787. However, it was always understood that the President could respond unilaterally to an attack, when time was of the essence; this has not changed. And a glance at the occasions where Presidents have acted on their own reveals no urgency that would render a congressional role impossible or impractical. In fact, speedier technology would make it much easier today to gather Congress and present it with information than was true centuries ago. One change that might argue for a more aggressive role is the atrophying of the Electoral College- the Framers believed it would guard against demagogues - and the recent weakening of political party organizations - party bosses tended to prefer candidates more moderate than party activists. But by themselves, these changes would not seem sufficiently potent to cast Congress aside.

Yet a key attribute of sovereignty is precisely the right and ability to make war. On the list of powers that "free and independent states" possess, for example, the Declaration of Independence lists first the right "to levy war [and] conclude peace." The international community, such as it is, is unconcerned with the intrastate maneuverings that preceded these decisions; its level of analysis is confined to the nation. But constitutionally, the internal events are of supreme importance. Can Congress re-delegate the power granted to it by the Constitution to the President? The growth of the administrative state has left the courts exceedingly reluctant to invoke the rule against re-delegation, for it seems so clearly impractical. But it is one thing to re-delegate to the executive the power to regulate, say, highway construction or small business loans, and quite another to do so on matters of war and peace.

When practice consistently departs from constitutional text, what to do? Courts have replied that practice illuminates the text, and with this hocus-pocus have eliminated the stark fact of contradiction. Put differently, the practical demise of the declare war clause and the acknowledged triumph of the presidency may be viewed as another example of the power of the Living Constitution approach to constitutional law. The originalist view centering on Congress has seemed impractical, outdated, and thus in need of reformulation. Both Congress and the Presidents have been willing, in fact often eager, to collude to bring about presidential dominance, never even hinting at its problematical constitutional status.

Is there any reason to suppose that requiring formal war declarations would change the current pattern of presidential initiation and congressional subservience? Perhaps, the war declaration's highlighting the issue in stark terms might alter the national debate, inducing caution in some and xenophobia in others. But it is hard to see how declarations could make a substantial difference. By definition, the declaration would occur at the beginning of the war, in other words, at the moment of public euphoria, when few elected officials would dare say no.

The President and Congress appear content with their present roles. Thus, declarations of war-in, say, an AUMF form, if not as formal declarations - are 
hardly dead letters. Presidents see the AUMFs' importance in mobilizing public support and dominating Congress. Some academics ${ }^{192}$ and pundits ${ }^{193}$ may press for formal declarations to strengthen Congress' hand, but Congress does not want its hand strengthened. With power comes responsibility, and Congress, for the most part, does not want responsibility. The presidential-congressional struggle that was supposed to ensue is nowhere to be seen. "The life of the law," as Holmes famously announced, "has not been logic. It has been experience," 194 and if the Constitution points to a congressionally centered reading of the war declaration clause, the two branches have long since settled into a presidentially centered mode. "The American people are not easily persuaded to embrace war," concluded one authority, ${ }^{195}$ but recent evidence strongly suggests otherwise. The Framers did not want war making to be easy, but in this their plans have failed. is neither.

Is the clause a dead letter or an invitation to struggle? The answer, it seems,

192 See, e.g.,Sidak \& Glennon, supra note 15.

193 See e.g., George Friedman, What Happened to the American Declaration of War?, ForBES (Mar. 30, 2011, 05:10pm), https://www.forbes.com/sites/beltway/2011/03/30/whathappened-to-the-american-declaration-of-war/.

194 Oliver W. Holmes JR. The Common LaW, 1 (1881).

195 Andrew J. Polsky, The Presidency at War: The Window of Agency in Wartime Presidential Leadership, in The Presidency and the Political System, 525, 529 (Michael Nelson ed. 2014). 